medRxiv preprint doi: https://doi.org/10.1101/2021.01.21.21249623; this version posted January 26, 2021. The copyright holder for this preprint

(which was not certified by peer review) is the author/funder, who has granted medRxiv a license to display the preprint in perpetuity.

All rights reserved. No reuse allowed without permission.

1 Article Summary Line: The COVID-19 pandemic has had an unprecedented impact on the

2 global community. Here we provide epidemiological and genomic details of the early stages of

3 the pandemic on Reunion Island.

4 Running Title: Genomics insight into early SARS-CoV-2 in Reunion Island

5 Keywords: SARS-CoV-2, Coronavirus, COVID-19, Genomics, Oxford Nanopore Technologies,

6 Reunion Island

7 Title: Genomic insights into early SARS-CoV-2 strains isolated in Reunion Island

8 Authors: *David A Wilkinson, Camille Lebarbenchon, Célestine Atyame, Sarah Hafsia, Marie-

9 Christine Jaffar-Bandjee, Luce Yemadje-Menudier, Sébastien Tanaka, Olivier Meilhac, *Patrick

10 Mavingui

$11 *$ Corresponding authors

\title{
12 Affiliations:
}

13 Université de La Réunion, UMR Processus Infectieux en Milieu Insulaire Tropical (PIMIT)

14 INSERM 1187, CNRS 9192, IRD 249, Sainte-Clotilde, La Réunion, France. (DA Wilkinson, C

15 Lebarbenchon, C Atyamé, S Hafsia, P Mavingui)

16 Centre Hospitalier Universitaire de la Réunion, Saint-Denis, France (O Meilhac, M-C Jaffar-

17 Bandjee)

18 Santé Publique France, Saint Denis, France (L Yemadje-Menudier)

19 Assistance Publique-Hôpitaux de Paris (AP-HP), Department of Anesthesiology and Critical

20 Care Medicine, Bichat-Claude Bernard Hospital, Paris, France (S Tanaka) 
medRxiv preprint doi: https://doi.org/10.1101/2021.01.21.21249623; this version posted January 26, 2021. The copyright holder for this preprint

(which was not certified by peer review) is the author/funder, who has granted medRxiv a license to display the preprint in perpetuity.

All rights reserved. No reuse allowed without permission.

21 Réunion Island University, French Institute of Health and Medical Research (INSERM), U1188

22 Diabetes atherothrombosis Réunion Indian Ocean (DéTROI), CYROI Plateform, Saint-Denis de

23 La Réunion, Réunion, France. Réunion Island University-affiliated Hospital, Réunion, France.

24 (O Meilhac, S Tanaka) 
27 The relative isolation of many island communities provides some protection from the COVID-19

28 pandemic, as imported cases can be limited and traced effectively. Until recently, this was true

29 for the population of the French overseas department, Reunion Island, where only limited

30 numbers of autochthonous cases were observed prior to August 2020. Since the report of the first

31 case of COVID-19, contact tracing has been carried out for each new case identified in Reunion

32 Island to identify transmission and clusters. To contribute to the public health response and

33 understand the diffusion of SARS-Cov-2 strains in Reunion Island, we established in-house

34 genome sequencing capability in Reunion using Oxford nanopore technology (MinION) as an

35 inexpensive option for genomic typing of SARS-CoV-2 lineages on the island, and cross-

36 validated typing results between viral isolation methods and different sequencing technologies.

37 The results of our work during the early phase of the epidemics are presented herein. 
medRxiv preprint doi: https://doi.org/10.1101/2021.01.21.21249623; this version posted January 26, 2021. The copyright holder for this preprint (which was not certified by peer review) is the author/funder, who has granted medRxiv a license to display the preprint in perpetuity.

All rights reserved. No reuse allowed without permission. 47 scale.

\section{Introduction:}

Severe acute respiratory syndrome coronavirus 2 (SARS-CoV-2) was first identified as the causative agent of coronavirus disease 2019 (COVID-19) in China in December 2019 after its emergence from wild animal populations[1]. Since, it has infected more than 45,000,000 individuals with 1.2 million deaths worldwide (at the time of writing). Its transmission has been rapid and widespread despite global intervention measures (such as quarantine and travel restrictions) due largely to the fact that viral transmission can occur from asymptomatic individuals and pre-symptomatic individuals[2]. This coupled with its relatively high case fatality rate[3] means that SARS-CoV-2 remains a public health emergency of unprecedented

The response to this pandemic has also been of an unprecedented scale. Governments have restructured healthcare systems to accommodate increased testing capacity for improved contact tracing, and genomics has played an important role in improving our understanding of COVID-19 transmission pathways and outbreaks[4,5]. As the number of acquired mutations in the SARS-CoV-2 genome has been relatively low over the course of the pandemic, whole genome sequencing has been essential to allow accurate strain typing, which in turn allows cases to be associated based on genetic similarity of the infecting strains. One study from Australia estimated that the use of genomic typing in conjunction with classical epidemiological tracing improved the case assignment rate by as much as $16 \%[6]$. Next generation sequencing has therefore been of great importance during the SARS-CoV-2 pandemic and emerging technologies such as Oxford Nanopore sequencing have made genomic approaches more accessible: To date, there have been more than 100,000 SARS-CoV-2 genomes deposited in the Global Initiative on Sharing All Influenza Data (GISAID) database[7]. 
medRxiv preprint doi: https://doi.org/10.1101/2021.01.21.21249623; this version posted January 26, 2021. The copyright holder for this preprint (which was not certified by peer review) is the author/funder, who has granted medRxiv a license to display the preprint in perpetuity.

All rights reserved. No reuse allowed without permission. largely subject to the same regulations concerning COVID-19-related practices as mainland approximately 850,000 people who live mainly in coastal regions. The population is relatively young, with people 65 years or over representing $8.1 \%$ fewer of the population than in mainland France (2020 institute of national statistics data, www.insee.fr/fr/statistiques). The first case of COVID-19 was reported in Reunion on 11th March 2020, four days before French regulations imposed strict lockdown measures which significantly reduced mobility across the country[8]. Prior to this in February, all direct commercial flights between Reunion and China had been suspended. In addition, lockdown measures provided effective protection for the Reunion population, meaning that numbers of cases remained low and were mainly imported as local inhabitants returned from areas of active SARS-CoV-2 circulation. Importantly, during this time most inbound flights were canceled, returning passengers were obliged to undergo a 14-day confinement period upon arrival, and all returning individuals were closely monitored by regional health authorities. Limited local virus circulation occurred in Reunion at this time, with approximately $70 \%$ imported cases and $30 \%$ autochthonous cases (defined as most likely local transmission with no history of travel), with a limited severity [9]. Subsequently, Reunion avoided the first pandemic wave that swept through Europe and placed the European population at the epicenter of the pandemic from March to April 2020. A timeline of reported cases and

80 important events in the epidemiology of COVID-19 on Reunion Island is presented in Figure 1.

81 Here we isolated and provided genomic data of SARS-CoV-2 strains circulating during the early

82 phase of the epidemics on Reunion Island. 
medRxiv preprint doi: https://doi.org/10.1101/2021.01.21.21249623; this version posted January 26, 2021. The copyright holder for this preprint (which was not certified by peer review) is the author/funder, who has granted medRxiv a license to display the preprint in perpetuity.

\section{Methodology:}

Patients and samples

85 Nasopharyngeal specimens were recovered either from patients admitted to CHU

Reunion or from outpatients, all with laboratory confirmed COVID-19. Before use, we ascertained the presence of viral genomic ARN in each specimen swab by real time RT-qPCR (described below). Samples were handled and stored at $-80^{\circ} \mathrm{C}$ in a biosecurity level three virology laboratory. Consent was obtained from each patient, classified as non-opposition, at the time of entry to the hospital.

\section{RNA Extraction and RT-qPCR}

Nucleic acids were extracted using the QIAamp Viral RNA mini kit (QIAGEN, Valencia, California, USA) and eluted in $60 \mu \mathrm{L}$ of AVE buffer. Reverse transcription was performed on 10 $\mu \mathrm{L}$ of RNA using the ProtoScript II Reverse Transcriptase and Random Primer 6 (New England BioLabs, Ipswich, MA, USA) as previously described[10]. cDNAs were tested for the presence of the N and Nsp14 genes using the PCR protocol published by The University of Hong Kong (https://www.who.int/publications/m/item/molecular-assays-to-diagnose-covid-19-summarytable-of-available-protocols). PCR were performed with the QuantiNova Probe RT-PCR Kit (QIAGEN, Valencia, California, USA) and $5 \mu$ L of cDNA in a CFX96 Touch $^{\text {TM }}$ Real-Time PCR Detection System (Bio-Rad, Hercules, CA, USA).

Viral isolation and production

SARS-CoV-2 strains were isolated in the African green monkey kidney cell line, Vero E6. Briefly, cells were cultured in a $25 \mathrm{~cm}^{2}$ flask containing $5 \mathrm{ml}$ of Eagle medium (MEM: Gibco/Invitrogen, Carlsbad, CA, USA) supplemented with 5\% heat-inactivated fetal bovine serum (FBS), $2 \mathrm{mmol} / \mathrm{L}$ L-Glutamine, $1 \mathrm{mmol} / \mathrm{L}$ sodium pyruvate, $100 \mathrm{U} / \mathrm{mL}$ of penicillin, 100 $\mu \mathrm{g} / \mathrm{mL}$ of streptomycin and $0.5 \mu \mathrm{g} / \mathrm{mL}$ of Amphotericin B (PAN Biotech, Aidenbach, Germany), at $37^{\circ} \mathrm{C}$ under a $5 \% \mathrm{CO}_{2}$ atmosphere. When cell density reached approximately $80 \%$, cells were 
medRxiv preprint doi: https://doi.org/10.1101/2021.01.21.21249623; this version posted January 26, 2021. The copyright holder for this preprint (which was not certified by peer review) is the author/funder, who has granted medRxiv a license to display the preprint in perpetuity.

All rights reserved. No reuse allowed without permission.

rinsed once with MEM medium supplemented with 2\% FBS, then 50 to $100 \mu 1$ of SARS-CoV-2positive swab specimen was mixed with 2 mL MEM 2\% FBS and layered on the Vero cell monolayer. After $2 \mathrm{~h}$ of incubation the inoculum was removed, cells were rinsed once and $6 \mathrm{~mL}$ of fresh MEM 2\% FBS medium was added. Flasks were incubated at $37^{\circ} \mathrm{C}$ in a $5 \% \mathrm{CO}_{2}$ atmosphere. Cultured were checked daily. Cell lines demonstrated a cytopathic effect 3 to 5 days post-infection. Supernatants of positive cultures were recovered, centrifuged at $400 \mathrm{X} \mathrm{g}$ for $5 \mathrm{~min}$ at $4^{\circ} \mathrm{C}$, then aliquoted and stored at $-80^{\circ} \mathrm{C}$ until used.

For viral production, a total of $100 \mu 1$ supernatant of positive culture was used to infect a monolayer of Vero cells grown in $75 \mathrm{~cm} 2$ flask as above. After three days, cytopathic effect was visible and the supernatant was recovered, cleared by centrifugation, aliquoted and stored at $80^{\circ} \mathrm{C}$.

\section{Viral titration}

Titration was performed by plaque-forming assay. Vero cells (cultured as above) were seeded in 6-well culture plates. Tenfold dilutions of SARS-CoV-2 solution were made in MEM $2 \%$ FBS culture medium and $500 \mu 1$ of each dilution was added to the cells in duplicate. After an incubation of $2 \mathrm{~h}$ at $37^{\circ} \mathrm{C}$ under a $5 \% \mathrm{CO}_{2}$ atmosphere, unabsorbed viral particles were removed and $2 \mathrm{ml}$ of culture medium supplemented with $0,8 \%$ carboxymethylcellulose (CMC; SigmaAldrich, Saint-Quentin-Fallavier, France) was added to each well and incubation was extended for 5 days. The CMC overlay was carefully removed, and the cells were fixed with $2 \mathrm{~mL}$ of 3.7 $\%$ paraformaldehyde in PBS. The plates were incubated at $37^{\circ} \mathrm{C}$ for $20 \mathrm{~min}$. The cells were then rinsed once with PBS and stained with $0.5 \%$ crystal violet in $20 \%$ ethanol. Plaques were visually counted and expressed as plaque-forming units per $\mathrm{mL}(\mathrm{PFU} / \mathrm{mL})$. 
medRxiv preprint doi: https://doi.org/10.1101/2021.01.21.21249623; this version posted January 26, 2021. The copyright holder for this preprint (which was not certified by peer review) is the author/funder, who has granted medRxiv a license to display the preprint in perpetuity.

All rights reserved. No reuse allowed without permission.

Nanopore (MinION) Sequencing and Analysis:

Genomes were sequenced from viruses originally infecting four independent patients.

132 Two samples (RUN-PIMIT1 and RUN-PIMIT2) were from couple of travelers returning from

133 France mainland. Sample RUN-PIMIT8 was obtained from a tourist originating from Greece

whereas sample RUN-PIMIT20 was quoted as real autochthonous case with unidentified contact with an imported case. We combined different sequencing technologies to cross-validate the sequences generated by different protocols. We also re-sequenced the same isolates from different passage histories to examine whether cell-line isolation may result in the accumulation of mutations.

In total, ten SARS-COV2 genomes were sequenced on a single Oxford Nanopore

protocol[11,12]. Following first-strand cDNA synthesis (as above), all sample preparation

methods followed the $\mathrm{nCoV}-2019$ sequencing protocol version 2 volume of Nanopore's small fragment buffer (SFB) to ensure that un-ligated barcode molecules 
medRxiv preprint doi: https://doi.org/10.1101/2021.01.21.21249623; this version posted January 26, 2021. The copyright holder for this preprint (which was not certified by peer review) is the author/funder, who has granted medRxiv a license to display the preprint in perpetuity.

All rights reserved. No reuse allowed without permission.

153 1000-fold for each genome. Basecalling and demultiplexing were performed using guppy

154 (v4.0.11). Basecalling used default parameters in accurate mode, and demultiplexing was

155 performed using the “--require_barcodes_both_ends" parameter to minimize sample crosstalk.

156 Reads were then assembled using Medaka v1.0.3 (https://nanoporetech.github.io/medaka/) as

157 part of the Artic network bioinformatics standard operating procedure

158 (https://artic.network/ncov-2019/ncov2019-bioinformatics-sop.html), subsampling amplicon

coverage to 400x and using genome accession MN908947.3 for read mapping. Geneious

v9.1.8[13] was used to inspect and curate mapped sequence data. Consensus base-calling

required a minimum of 30 -fold coverage.

162

\section{Illumina Sequencing and Analysis:}

Four of the SARS-CoV-2 samples ( 2 isolates and 2 swabs) that were sequenced using the ONT amplicon protocol were additionally sequenced using an Illumina shotgun method from unamplified cDNA in order to complete genomic loci that were poorly amplified by the tiling PCR and to allow cross validation of the ONT sequencing methodology against the Illumina gold standard.

Briefly, sequencing libraries were generated from $10 \mathrm{ng}$ of cDNA using the Celero ${ }^{\mathrm{TM}}$ PCR Workflow with Enzymatic fragmentation (DNA-Seq) following the manufacturer's instructions. Sequencing was performed on the MiSeq platform, with $1 * 170 \mathrm{bp}$ single end reads. Demultiplexed sequences were provided by the sequencing company (Biofidal, Lyon, France). Sequences were quality trimmed and adapters removed using Trimmomatic v0.39. Trimmed reads were mapped to reference sequence MN908947.3 using minimap2 v.2.17- 
medRxiv preprint doi: https://doi.org/10.1101/2021.01.21.21249623; this version posted January 26, 2021. The copyright holder for this preprint (which was not certified by peer review) is the author/funder, who has granted medRxiv a license to display the preprint in perpetuity.

All rights reserved. No reuse allowed without permission.

$174 \mathrm{r} 941[14]$. Geneious v9.1.8[13] was used to inspect and curate mapped sequence data and

175 consensus sequences.

176 Genome typing:

177 Assembled genomes were assigned to global major lineages using pangolin v.2.0.5[15] to

178 compare to the pangoLEARN database (version from 20th July 2020), default parameters were

179 used for quality control filtering and probability scores for lineage calling.

180

181

182

183

184

185

186

187

188

189

190

191

192

193

194

195

196

\section{Results and Discussion:}

MinION sequencing generated complete genomic data sets for six of the eight sequenced

isolates and for one swab out of two (Table 1). The remaining three samples (two isolates and one swab) demonstrated high $\mathrm{Ct}$ values when detecting viral cDNA by qPCR, suggesting that the concentrations of virus in these samples were low. PCR amplification was not uniform in these samples and genomic assemblies had short gaps where 30-fold coverage was not achieved. The primers used in the tiling protocol are unable to target the 3' and 5' extremities of the virus, and therefore all assemblies were missing 54 bases from the 5' extremity and 67 bases from the 3' extremity.

Illumina shotgun sequencing produced near-complete genome assemblies for four of the samples (two isolates and two swabs), again only excluding 5' and 3' extremities of the genome, which had limited coverage that varied between isolates. By combining Illumina and MinION data mapped to the same reference strain we were able to improve the genomic assemblies for these four genome sequences. Furthermore, in genomic regions that were successfully sequenced by both approaches, no disagreements were observed in consensus sequences generated by

MinION and Illumina sequencing. However, MinION assemblies had a slightly higher proportion of ambiguous base calls. 
medRxiv preprint doi: https://doi.org/10.1101/2021.01.21.21249623; this version posted January 26, 2021. The copyright holder for this preprint (which was not certified by peer review) is the author/funder, who has granted medRxiv a license to display the preprint in perpetuity.

All rights reserved. No reuse allowed without permission.

Sequencing data are summarized in Table 1.

Resequencing of isolated passage variants produced identical sequence variants to the parental strain in each instance (Table 2), suggesting that the process of viral isolation and passaging (in this case in Vero E6 cells) does not select for mutant variants.

Typing assigned all genomes to pangolin lineage B.1, either belonging to GISAID

lineage G, or GH (Table 2) which (along with lineage GR) are the prevailing lineages circulating globally at the time of writing [16]. Phylogenetic analysis identified three different sequence variants, which differed from each other by a maximum of seven mutations (Figure 2).

\section{Conclusion:}

Our findings provide support that MinION sequencing can be successfully applied for rapid sequencing and generation of genomic data in remote locations, such as on Reunion Island. Paired comparison with genomes obtained with Illumina sequencing further highlight that the quality of the generated sequences can be used confidently in molecular epidemiology and phylodynamic studies.

Additionally, we observed that viral isolation, limited passaging and production in Vero E6 cell lines were not associated with the selection of mutations that could bias genomic typing results. This is important due to the strong genetic similarity between prevailing SARS-CoV-2 lineages and because cell-line based viral amplification is a useful method for extracting increased quantities of viral material when direct sequencing of swabs with low viral loads may provide incomplete genomic data.

At the time of writing, Reunion Island is facing its first wave of COVID-19 infection, with more than 400 cases of COVID-19 reported weekly[17]. As has been demonstrated 
219 elsewhere, genomic data can be used to significantly improve the case assignment rate and

220 contact tracing measures that help to mitigate future disease[6]. Phylodynamic investigations

221 based on these data can also inform the timing and origin of viral introduction, as well as their

222 local transmission dynamics and epidemiological characteristics. Thus, the capacity to perform

223 in-house, rapid and comparatively cheap genomic typing of SARS-CoV-2 isolates will hopefully

224 play an important role in improving Reunion Island's response to the COVID-19 pandemic.

225 These analyses are intended to continue on a larger local scale in Reunion Island in order to

226 understand the circulation of SARS-CoV-2 during the current, largely autochthonous, COVID-

22719 epidemic wave. 
medRxiv preprint doi: https://doi.org/10.1101/2021.01.21.21249623; this version posted January 26, 2021. The copyright holder for this preprint

(which was not certified by peer review) is the author/funder, who has granted medRxiv a license to display the preprint in perpetuity.

All rights reserved. No reuse allowed without permission.

229 This research was funded by Université de La Réunion (COVID-19 emergency seed funding).

\section{Conflicts of interest:}

Authors declare no conflicts of interest.

232

233

234

235

236

237

238

239

240

241

242

243

244

245

246

247

248

\section{References}

1. Zhou P, Yang X Lou, Wang XG, Hu B, Zhang L, Zhang W, et al. A pneumonia outbreak associated with a new coronavirus of probable bat origin. Nature. 2020. doi:10.1038/s41586-020-2012-7

2. Mizumoto K, Kagaya K, Zarebski A, Chowell G. Estimating the asymptomatic proportion of coronavirus disease 2019 (COVID-19) cases on board the Diamond Princess cruise ship, Yokohama, Japan, 2020. Eurosurveillance. 2020. doi:10.2807/15607917.ES.2020.25.10.2000180

3. Verity R, Okell LC, Dorigatti I, Winskill P, Whittaker C, Imai N, et al. Estimates of the severity of coronavirus disease 2019: a model-based analysis. Lancet Infect Dis. 2020. doi:10.1016/S1473-3099(20)30243-7

4. Geoghegan JL, Ren X, Storey M, Hadfield J, Jelley L, Jefferies S, et al. Genomic epidemiology reveals transmission patterns and dynamics of SARS-CoV-2 in Aotearoa New Zealand. medRxiv. 2020. doi:10.1101/2020.08.05.20168930

5. Candido DS, Claro IM, de Jesus JG, Souza WM, Moreira FRR, Dellicour S, et al. Evolution and epidemic spread of SARS-CoV-2 in Brazil. Science (80- ). 2020. doi:10.1126/science.abd2161 
6. Rockett RJ, Arnott A, Lam C, Sadsad R, Timms V, Gray KA, et al. Revealing COVID-19 transmission in Australia by SARS-CoV-2 genome sequencing and agent-based modeling. Nat Med. 2020. doi:10.1038/s41591-020-1000-7

7. Shu Y, McCauley J. GISAID: Global initiative on sharing all influenza data - from vision to reality. Eurosurveillance. 2017. doi:10.2807/1560-7917.ES.2017.22.13.30494

8. Ruktanonchai NW, Floyd JR, Lai S, Ruktanonchai CW, Sadilek A, Rente-Lourenco P, et al. Assessing the impact of coordinated COVID-19 exit strategies across Europe. Science (80- ). 2020. doi:10.1126/science.abc5096

9. COVID-19 $\square$ : point épidémiologique à la Réunion du 13 août 2020. [cited 6 Nov 2020]. Available: https://www.santepubliquefrance.fr/regions/ocean-indien/documents/bulletinregional/2020/covid-19-point-epidemiologique-a-la-reunion-du-13-aout-2020

10. Lebarbenchon C, Ramasindrazana B, Joffrin L, Bos S, Lagadec E, Le Minter G, et al. Astroviruses in bats, Madagascar. Emerg Microbes Infect. 2017;6: e58. doi:10.1038/emi.2017.47

11. Quick J, Grubaugh ND, Pullan ST, Claro IM, Smith AD, Gangavarapu K, et al. Multiplex PCR method for MinION and Illumina sequencing of Zika and other virus genomes directly from clinical samples. Nat Protoc. 2017. doi:10.1038/nprot.2017.066 amplicon-based sequencing framework for accurately measuring intrahost virus diversity using PrimalSeq and iVar. Genome Biol. 2019. doi:10.1186/s13059-018-1618-7 
Basic: An integrated and extendable desktop software platform for the organization and analysis of sequence data. Bioinformatics. 2012. doi:10.1093/bioinformatics/bts199

14. Li H. Minimap2: Pairwise alignment for nucleotide sequences. Bioinformatics. 2018. doi:10.1093/bioinformatics/bty191

274

275

15. Rambaut A, Holmes EC, O’Toole Á, Hill V, McCrone JT, Ruis C, et al. A dynamic nomenclature proposal for SARS-CoV-2 lineages to assist genomic epidemiology. Nat Microbiol. 2020. doi:10.1038/s41564-020-0770-5

16. Mercatelli D, Giorgi FM. Geographic and Genomic Distribution of SARS-CoV-2 Mutations. Front Microbiol. 2020;11: 1800. doi:10.3389/fmicb.2020.01800

17. COVID-19 $\square$ : point épidémiologique à la Réunion du 29 octobre 2020. [cited 6 Nov 2020]. Available: https://www.santepubliquefrance.fr/regions/oceanindien/documents/bulletin-regional/2020/covid-19-point-epidemiologique-a-la-reuniondu-29-octobre-2020

18. Year-letter Genetic Clade Naming for SARS-CoV-2 on Nextstain.org. [cited 11 Sep 2020]. Available: https://nextstrain.org/blog/2020-06-02-SARSCoV2-clade-naming 
medRxiv preprint doi: https://doi.org/10.1101/2021.01.21.21249623; this version posted January 26, 2021. The copyright holder for this preprint (which was not certified by peer review) is the author/funder, who has granted medRxiv a license to display the preprint in perpetuity.

All rights reserved. No reuse allowed without permission.

286 Address for correspondence:

287 Dr David A Wilkinson, UMR Processus Infectieux en Milieu Insulaire Tropical (PIMIT)

288 INSERM 1187, CNRS 9192, IRD 249, 2 Rue Maxime Rivière, Sainte-Clotilde, La Réunion,

289 France. Email : david.wilkinson@ univ-reunion.fr

290 Dr Patrick Mavingui, UMR Processus Infectieux en Milieu Insulaire Tropical (PIMIT) INSERM

291 1187, CNRS 9192, IRD 249, 2 Rue Maxime Rivière, Sainte-Clotilde, La Réunion, France.

292 Email : patrick.mavingui@cnrs.fr 


\begin{tabular}{|c|c|c|c|c|c|c|c|c|c|c|c|c|c|}
\hline \multirow[b]{2}{*}{ ID } & \multirow{2}{*}{$\begin{array}{c}\text { Swab (S) } \\
\text { or Culture } \\
\text { (C) }\end{array}$} & \multirow{2}{*}{$\begin{array}{l}\text { Isolation/ } \\
\text { Passage } \\
\text { Details }^{+}\end{array}$} & \multicolumn{4}{|c|}{ MinION, amplicon tiling } & \multicolumn{4}{|c|}{ Illumina } & \multicolumn{3}{|c|}{ Combined } \\
\hline & & & Complete & Missing & Ambiguities & Coverage** & Complete & Missing & Ambiguities & Coverage & Complete? & Missing & Ambigigi \\
\hline $\begin{array}{l}\text { hCoV-19/Réunion/RUN- } \\
\text { PIMIT20 }\end{array}$ & $\mathrm{C}$ & Vero E6 & No & $1.7 \%$ & 1 & $407 x$ & Yes* & $2.1 \%$ & 0 & $1500 x$ & Yes* & $0.1 \%$ & 造 \\
\hline $\begin{array}{l}\text { hCoV-19/Réunion/RUN- } \\
\text { PIMIT1 }\end{array}$ & $\mathrm{S}$ & NA & Yes* & $0.4 \%$ & 0 & $435 \mathrm{x}$ & Yes* & $2.1 \%$ & 0 & $3250 x$ & Yes* & $0.1 \%$ & 离施 \\
\hline $\begin{array}{l}\text { hCoV-19/Réunion/RUN- } \\
\text { PIMIT2 }\end{array}$ & $\mathrm{S}$ & NA & No & $1.5 \%$ & 1 & $356 x$ & Yes* & $2.4 \%$ & 0 & $675 x$ & Yes* & $0.2 \%$ & 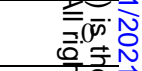 \\
\hline $\begin{array}{c}\text { hCoV-19/Réunion/RUN- } \\
\text { PIMIT8 }\end{array}$ & $\mathrm{C}$ & Vero E6 & Yes* & $0.4 \%$ & 0 & $413 x$ & Yes* & $0.1 \%$ & 0 & $1700 x$ & Yes* & $0.1 \%$ & \\
\hline RUN-PIMIT1c & $\mathrm{C}$ & $\begin{array}{l}\text { RUN-PIMIT1a, } \\
\text { passage } 1\end{array}$ & Yes* & $0.4 \%$ & 0 & $385 x$ & - & - & - & - & - & - & \\
\hline RUN-PIMIT1d & $\mathrm{C}$ & $\begin{array}{l}\text { RUN-PIMIT1c, } \\
\text { passage } 2\end{array}$ & Yes* & $0.4 \%$ & 0 & $423 x$ & - & - & - & - & - & - & \\
\hline RUN-PIMIT1a & $\mathrm{C}$ & $\begin{array}{l}\text { RUN-PIMIT1, } \\
\text { Vero E6 }\end{array}$ & No & $1.4 \%$ & 0 & $336 x$ & - & - & - & - & - & - & 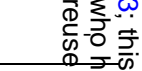 \\
\hline RUN-PIMIT1b & $\mathrm{C}$ & $\begin{array}{l}\text { RUN-PIMIT1, } \\
\text { Vero E6 }\end{array}$ & Yes* & $0.4 \%$ & 0 & $404 x$ & - & - & - & - & - & - & 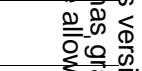 \\
\hline RUN-PIMIT20a & $\mathrm{C}$ & $\begin{array}{l}\text { RUN-PIMIT20, } \\
\text { Vero E6 }\end{array}$ & Yes* & $0.4 \%$ & 0 & $407 x$ & - & - & - & - & - & - & 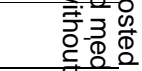 \\
\hline
\end{tabular}

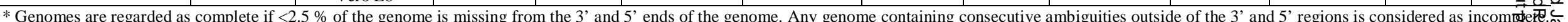

** MinION coverage is calculated by mapping in Medaka after subsampling sequence coverage to a maximum of $400 x$ per primer pair. Overlapping regions increase average coverage.

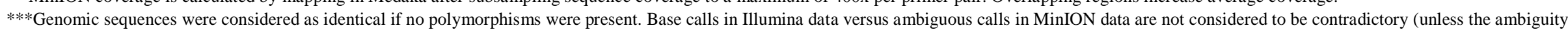
the base call in the Illumina sequence).

+ For cultured isolates, cell lines are indicated. For isolates that are resequenced from previous passages, corresponding parental strain is indicated. 
medRxiv preprint doi: https://doi.org/10.1101/2021.01.21.21249623; this version posted January 26, 2021. The copyright holder for this preprint (which was not certified by peer review) is the author/funder, who has granted medRxiv a license to display the preprint in perpetuity.

All rights reserved. No reuse allowed without permission.

294 Table 2. Lineage typing data of different isolates.

\begin{tabular}{|c|c|c|c|c|c|}
\hline ID & $\begin{array}{c}\text { Pangolin } \\
\text { lineage }\end{array}$ & $\begin{array}{l}\text { GISAID } \\
\text { lineage }\end{array}$ & $\begin{array}{l}\text { Year/Letter } \\
\text { lineage* }\end{array}$ & Isolate history & $\begin{array}{l}\text { Mutations from } \\
\text { parent strain }\end{array}$ \\
\hline $\begin{array}{l}\text { hCoV-19/Réunion/RUN- } \\
\text { PIMIT1 }\end{array}$ & B.1 & $\mathrm{G}$ & $20 \mathrm{~A}$ & Swab & NA \\
\hline RUN-PIMIT1a & B.1 & G & $20 \mathrm{~A}$ & $\begin{array}{l}1^{\text {st }} \text { generation } \\
\text { isolate }\end{array}$ & 0 \\
\hline RUN-PIMIT1b & B. 1 & $\mathrm{G}$ & $20 \mathrm{~A}$ & $\begin{array}{l}1^{\text {st }} \text { generation } \\
\text { isolate }\end{array}$ & 0 \\
\hline RUN-PIMIT1c & B.1 & G & $20 \mathrm{~A}$ & $\begin{array}{l}2^{\text {nd }} \text { generation } \\
\text { passage }\end{array}$ & 0 \\
\hline RUN-PIMIT1d & B. 1 & G & $20 \mathrm{~A}$ & $\begin{array}{l}3^{\text {rd }} \text { generation } \\
\text { passage }\end{array}$ & 0 \\
\hline $\begin{array}{c}\text { hCoV-19/Réunion/RUN- } \\
\text { PIMIT2 }\end{array}$ & B. 1 & G & $20 \mathrm{~A}$ & Swab & NA \\
\hline RUN-PIMIT2a & B.1 & G & $20 \mathrm{~A}$ & $\begin{array}{l}1^{\text {st }} \text { generation } \\
\text { isolate }\end{array}$ & 0 \\
\hline $\begin{array}{c}\text { hCoV-19/Réunion/RUN- } \\
\text { PIMIT8 }\end{array}$ & B. 1 & $\mathrm{GH}$ & $20 \mathrm{C}$ & $\begin{array}{l}1^{\text {st }} \text { generation } \\
\text { isolate }\end{array}$ & NA \\
\hline $\begin{array}{c}\text { hCoV-19/Réunion/RUN- } \\
\text { PIMIT20 }\end{array}$ & B.1 & G & $20 \mathrm{~A}$ & $\begin{array}{l}1^{\text {st }} \text { generation } \\
\text { isolate }\end{array}$ & NA \\
\hline RUN-PIMIT20a & B. 1 & G & $20 \mathrm{~A}$ & $\begin{array}{l}2^{\text {nd }} \text { generation } \\
\text { passage }\end{array}$ & 0 \\
\hline
\end{tabular}

*Year/Letter lineage as defined by Hodcroft et al.[18] 
medRxiv preprint doi: https://doi.org/10.1101/2021.01.21.21249623; this version posted January 26, 2021. The copyright holder for this preprint

(which was not certified by peer review) is the author/funder, who has granted medRxiv a license to display the preprint in perpetuity.

All rights reserved. No reuse allowed without permission.

Reserved space. Do not place any text in this section. Include the mandatory author checklist or your manuscript will be returned. Use continuous line numbering in your manuscript.

295 Figure 1: Epidemiological timeline of COVID-19 cases in Reunion Island corresponding to the

296 first six months since the first identified cases (11th March 2020 - 11 September 2020).

297 Figure 2: Phylogenetic tree and pairwise mutation number between genomes of SARS-CoV-2

298 from independent cases in La Reunion. 
a. hCov-19/Reunion/RUN-PIMIT8 (GH/20C)

b. hCov-19/Reunion/RUN-PIMIT20 (G/20A)

c. hCov-19/Reunion/RUN-PIMIT1 (G/20A)

d. hCov-19/Reunion/RUN-PIMIT2 (G/20A)

\begin{tabular}{|l|l|l|l|}
\hline 0 & 7 & 7 & 7 \\
\hline 7 & 0 & 2 & 2 \\
\hline 7 & 2 & 0 & 0 \\
\hline 7 & 2 & 0 & 0 \\
\hline
\end{tabular}

Pairwise mutation number 